\title{
Creating Innovation in Education by Using Value Analysis System
}

\author{
Abduloh \\ Universitas Singaperbangsa \\ Karawang, Jawa Barat, Indonesia \\ abduloh175@gmail.com
}

\begin{abstract}
Human being are social creatures that cannot be separated from the other creatures. In their life, they are required to think because they will always socialize and interact with others. As a result, this will give an impact on the increasing needs and will also arise various problems as well as dynamics of a complex life either individually or in groups. To overcome this situation, a nation or country can be said to be developed if the citizens think actively, solve problem creatively, and find solutions innovatively. Therefore, creating innovation in education is very important because the quality of innovation can solve complex problems. One of the ways to create innovation in education is using value analysis system. This article was written with a qualitative approach on the study of theoretical analysis. The benefits of using the value analysis system are improving and changing aspects including Theology, Ethic, Aesthetics, Physical aspect, Logic, and Theolologic.
\end{abstract}

Keywords-Education Innovation, Value Analysis System

\section{INTRODUCTION}

The era of globalization is one of the modernization developments characterized by an interdependence. Interdependence in this case is characterized by increasing sophisticated means of communication and interaction, which can rise the competition in ideological, political, economic, social and cultural aspects. It can also rise the dynamics and problems of life which are more complicated and complex. The era of globalization is often expressed as the era full of challenges and opportunities for cooperation. In facing the new world which is full of change and the dynamics, the situation today has brought variety of implications for many areas of life, including the demands and the development of communication and social interaction in a process of development of science and technology as the result of innovation.

In writing this article, a qualitative approach to the study of the theory of theoretical analysys was used. This article focuses on the study about "Creating Education Innovations by Values System Analysis". Before proceeding into the study of Creating Education Innovations by values system analysis, characteristics of innovation and values system should be explored first. The characteristics of innovations explained by [1] are as follows:

- Relative Advantage, is the degree that an innovation is perceived as better or superior then ever existed. This can be measured by various factors such as economic, social prestige, comfort and satisfaction. The more relative advantage felt by adopters, the faster the innovation can be adopted.

- Compatibility, refers to the degree that an innovation is considered to be consistent by prevailing values, past experiences, and needs of adopters. For example, if a particular innovations or new ideas are not appropriate with the values and norms, the innovation cannot be adopted easily.

- Complexity, is the degree that an innovation is regarded as difficult to understand and use. Some specific innovations can be easily understood and used by adopters and some are otherwise. The more easier the innovation is understood by the adopters, the faster an innovation can be adopted.

- Trialability, is the degree that an innovation can be tested to certain extent. An innovation that can be tested in real settings will generally be quickly adopted. So, in order to rapidly adopted, an innovation must be able to express its superiority.

Subsequently, the innovative approaches which have life values system can be described, cognitively, within six systems of values:

(1) Theological value, which is reflected among other things in the Almighty God, Pillars of Iman (6) Pillars of Islam (5) Praying, monotheism, charity, forgiveness, prayer, sincere, repentance, ijtihad, khusyu istikamah, and jihad fi sabililldh.

(2) Value ethical-legal, which is reflected among other things in a respectful, kind/humble, loyal, trustworthy, honest, responsible, good faith, fair faithful, peace, patience, forgiveness, helpfulness, tolerance and harmony.

(3) Aesthetic value, which is reflected among others, in a state of nice, clean, beautiful, pretty, sweet, charming, harmonious, romantic, and love. Value logical-rational, which is reflected in logic/match between facts and conclusions, right, appropriate, clear, tangible, identity/characteristics, process, and conclusion match.

(4) Physical-physiological value which is reflected clearly in its elements, functions, size, strength, changes, location, origin, cause and effect.

(5) Teleological value which is reflected embodied in a useful, beneficial, according to the function, 
developing/developed, regular/discipline, integrative, productive, effective, efficient, accountable, innovative [1].

\section{THEORETICAL BASIS}

In Islam, human as individual and member of society has the rights to do, to act and to behave appropriately by volition of the will and freedom. However, human is also bound by the norms, values, regulation and law in society, even by the provisions of the applicable in religious beliefs [2]. This is what distinguishes humans as social beings with other creatures. Humans created by God as social beings who need social relationships and interactions with others to solve the problem. It means that humans can establish fraternity or brotherhood (ukhuwah) as one of the teachings that gets important attention in Islam.

From the description, human can be described as a social creature who has interdependence and mutual need and interact and work together to solve problems. The problem solving (solutions) should have wisdom as recent findings (innovation).

Innovation is a new invention that was discovered by an individual/or groups both in the form of services and goods which have use value and benefits for improving and changing to a better life than previous life.

Furthermore, education is a learning process based on the interaction between educators and learners for achieving certain objectives [3], so education is a process of various activities of the body and soul in effort to reach certain purposes through the process of thinking and creative as well as productive activities in solving problems. The effort should be made to find something that is useful and valuable (innovative).

The complexity is a complex issue that must be solved and sought as root of the problem and seek a solution in solving the problem. It is expected that educators and learners can be active thinker, creative, innovative and productive in finding a solution to the existing problems. Moreover, value system is the norm as a benchmark of an innovation that has a role and function for the adopters or users or for interested party so that it has benefits for the improvement and change either individually or in groups [1].

\section{DISCUSSION}

All of the problems demand a solution by the humans because every human being is given the ability and physical and psychological strength. Humans can solve problems if they would think and use the skills they have. This case needs no motivation of forming human commitment and consistency in thinking in order to solve problems with effective and efficient solutions.

Motivation exists to form the commitment and consistency to be active and creative thinker. People can activate the five senses, namely sight, hearing, smelling, tasting and touching. The five senses as tools to transport the data and information that can be processed by the brain into a source of knowledge as a source or material innovation.

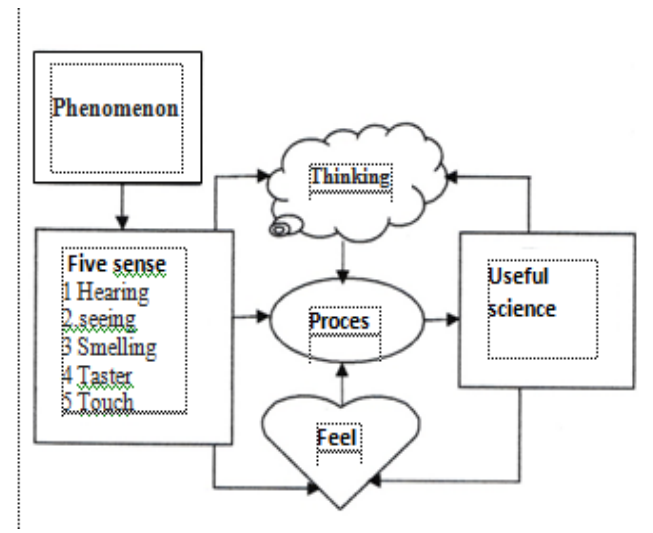

Fig. 1. Transferring the material senses innovation

To create an innovation with creative thinking in solving complex problems, the innovators must be able to think about (1) the advantage (distinct), whether related to the effectiveness, efficiency, productivity, flexibility, relevance and continuity, or a goods or services that have been there (Innovation). (2) the norms or rules that are related with ethics (attitude) and aesthetic (art) which have been appointed by users or adopters of innovation in order to have relevance and benefits. (3) the level of complexity that an innovation should be easy, simple, practical, flexible, logical (logic) and can be adopted and developed. (4) the quality and excellence possessed by the results of innovation (5) concrete result of innovation which can be observed and perceived by the five senses so that the values and their benefits (teleological) can be felt.

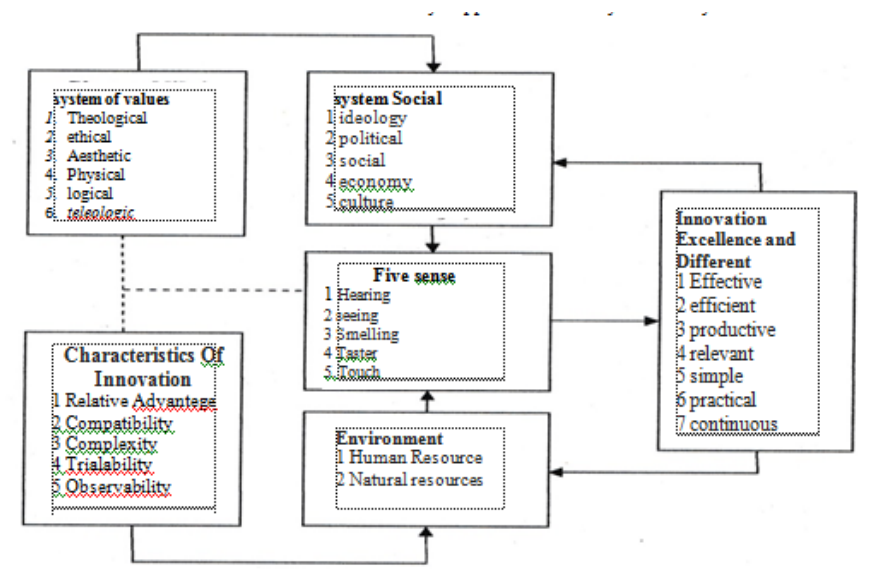

Fig. 2. Education Innovation by Approach of Values System Analysis

\section{CONCLUSION}

Creating educational innovation in the complexity of the value system analysis is an activity of the role and functions of the five senses as sources or material to think actively, creatively and productively, so an innovation can be created that has value and benefits including effective values, efficient, productive, relevant, flexible, elastic, simple, practical, and continuous. 


\section{REFERENCES}

[1] E. M. Rogers, Diffusion of Innovations, New York: Free Press, 1983.

[2] S. Ahmad, System Nilai Alternatif wajah-wajah pendidikan, Bandung: Nuansa Cendikia, 2015.
[3] S. Sauri, Pendidikan Karakter dalam Perspektif Islam, Bandung: Rizqi Press, 2013.

[4] Sukmadinata and Nana Saodih, Pengembangan Kurikulum teori dan praktik, Bandung: Remaja Rosdakarya, 2001. 